


\section{AMSTER, PAPELUCHO Y YO}

Pablo Rivas

Soy un apasionado de la lectura. Nada en mi formación puede justificar adecuadamente esta afición. Siendo miembro de una familia de clase media, sin tradición literaria -ni de ningún tipo en realidad-, y criado en el Puente Alto de los años ochenta, sufrí una permanente escasez de libros. Forzosamente leía cuanto caía en mis manos: enciclopedias de bolsillo, diccionarios, los libros que venían en las Tareas Escolares Zig-Zag. Las fuentes eran variadas y la calidad dispar. En mi infancia leí buenos y malos libros. Con una fuerte inclinación por lo segundo. Libros de discutible calidad literaria y pésima confección. Pero también estaban los buenos libros. Y aunque en ese momento no lo sabía, Mauricio Amster era en parte responsable de eso.

A pesar de la precariedad cultural en la que me vi sumergido durante mi infancia, no puedo ignorar los esfuerzos que mis padres realizaron para revertir la situación. Una de estas medidas fue comprar la colección entera de Papelucho, la serie infantil escrita por Marcela Paz. Eventualmente llegué a tener los doce títulos. Me dediqué veranos enteros a leerlos y releerlos. Fueron por lejos la lectura más provechosa e intensa de mi infancia. Recuerdo vívidamente los calurosos días de Enero capeados bajo el cobertizo del patio de mi casa en Puente Alto. En ese lugar leía Papelucho. ¿Cuántos años tendría? Siete años, ocho a lo sumo.

Mientras recuerdo, trato de definir que hizo a estos libros tan especiales y distintos a todo lo demás que leí en la época. Pienso que pudo haber sido la sensación de 
serialidad. Recuerdo el placer de juntar los doce libritos, lomo a lomo, y descubrir que todos eran iguales pero, al mismo tiempo, distintos. El lomo y la contratapa de cada título venían con un color distinto. Mi Hermano Hippie era color mostaza; ¿Soy Dixleso? Era amarillo brillante; Papelucho Perdido era naranjo. Pero todos los lomos estaban compuestos, rigurosamente, de igual manera. En la base el emblema de la Editorial Universitaria -creado por el mismo Amster-, "Marcela Paz" seguía, en altas cursivas. El titulo en altas iba alineado a la derecha, vale decir, a la parte superior del lomo. iEl regocijo de contemplar los doce juntos!

Pasarían dieciséis años para que pudiese darle un nombre al autor intelectual de ese placer. Ninguna sorpresa aquí: Mauricio Amster. Siendo diseñador, ¿́puedo justificar mi ignorancia supina a lo largo de todos estos años? Difícilmente. El nombre estuvo ahí todo el tiempo, en los créditos del libro. "Proyectó la edición Mauricio Amster."

Son muchas las razones por las cuales estos libros significan tanto para mí. Las historias de Papelucho son importantes, naturalmente. Pero hay algo más. Había algo en el diseño. Pudo ser la tipografía, Photon Perpetua, compuesta en 12 con espaciado 14 y su sutil aspecto de antigüedad; o la intriga que me producía esa numeración de páginas, esos números caídos y elevados. Mucho tiempo después descubriría que se trataban de números de caja baja, no alineados o "colgantes"; o también pudo ser la manipulabilidad -esa construcción del objeto perfecto para las manos- que no se puede determinar exactamente en que reside; o las ilustraciones que aparecian continuamente, salpicadas por el texto en formas siempre apropiadas.

Pero creo que lo que me gustaba de estos libros, después de todo, era la calidad. A pesar de que la educación y el refinamiento son condiciones determinantes para el disfrute de la excelencia, existe también un nivel instintivo donde hasta un niño de Puente Alto puede darse cuenta de que lo que tiene en sus manos es valioso. 
Supongo que eso me pasaba con los libros de Papelucho. Tenía el conocimiento secreto de que en mis manos guardaba un pequeño tesoro.

Nunca podré agradecer a Amster su trabajo. Su. profesionalismo $y$ talento hicieron posible que $\mathrm{mi}$ introducción a la lectura -con la cual mantengo una saludable relación hasta hoy- fuese placentera, agradable. La serie de Papelucho fue uno de sus últimos trabajos, desarrollados durante la década de los setenta. Las distintas ediciones han variado mucho en la calidad de los materiales usados. El papel, por ejemplo, decayó continuamente de edición en edición. Y también sé que no es uno de sus trabajos más logrados. Sin embargo, para mí, Amster fue el creador del universo de letras que hasta el día de hoy me acompaña. Supongo que tuve suerte 